See discussions, stats, and author profiles for this publication at: https://www.researchgate.net/publication/330452854

\title{
Forthcoming: Slavery and its Obligations Erga Omnes
}

Article $\cdot$ January 2019

CITATIONS

0

1 author:

(2) Jean Allain

Monash University (Australia)

125 PUBLICATIONS 331 CITATIONS

SEE PROFILE

Some of the authors of this publication are also working on these related projects:

Property Rights and Human Rights in a Global Context View project

Human Exploitation in Domestic Legislation View project
READS

113 


\title{
Slavery and its Obligations Erga Omnes
}

\author{
Jean Allain*
}

\section{Introduction}

The prohibition of slavery holds a special place in the pantheon of international law as it benefits from the protection afforded to it by obligations erga omnes. Despite slavery having been highlighted as such by the International Court of Justice ('International Court') in the 1970 Barcelona Traction case, the reality was - rather surprisingly — that at the time, the prohibition of slavery was effectively dead-letter law. As slavery had for so long been associated with legal ownership, and as most jurisdictions had abolished such laws by the early $20^{\text {th }}$ century, slavery was considered to no longer exist, rendering any obligations, erga omnes or otherwise, moot.

Yet, this consensus came to be challenged during the first decade of the $21^{\text {st }}$ century, in part as a result of the establishment of enslavement and sexual slavery as international crimes, and the incorporation of slavery into the definition of human trafficking. More recently, in 2016, the Inter-American Court of Human Rights recognised the extension of the prohibition of slavery beyond legal ownership of a person to include de facto situations of slavery. As such, the near-century long lack of practical relevance of the application of a right not to be held in slavery has emerged, and with it the possibility to consider the reaches of its obligations, including those erga omnes.

This article explores the modern relevance of obligations of international law as they pertain to slavery. It first considers the classic and modern content of 'slavery', and then turns to examine the extent of the obligations of States to 'abolish' and 'prohibit' slavery. It argues that the expansion in the understanding of slavery in the modern world has brought to life existing treaty and customary international law obligations in relation to slavery, requiring States to do more than merely abolish laws that explicitly allow one human being to hold legal ownership rights over another person. In first considering the normative content of slavery, this study sets out general obligations flowing from such a prohibition, so as to then turn to focus on two situations as the basis for analysing the parameters of obligations erga omnes. In the first instance, the obligations which States have undertaken in treaty-law in regard to the prohibition of slavery are considered so as to shine a light on the failure of nearly half of all States to effectively incorporate the prohibition of slavery into their domestic legal order. Through such a consideration it becomes clear that where the prohibition of slavery is found in treaty-law, so too are obligations arising erga omnes partes.

Beyond such considerations, attention turns to the serious breach of the prohibition of slavery perpetuated by the Islamic State of Iraq and Al-Sham (ISIS) against Yazidi girls and women. Recognising that ISIS is a non-State entity, and thus not bound by the regime of State Responsibility, this study nevertheless uses its wholesale reintroduction of the slave trade as a vehicle for examining, in general terms, the requirements of obligations erga omnes. As in the case of ISIS, where there is serious breach of the prohibition of slavery, it will be argued that there remains an underlying communal interest for all States to cooperate in bringing such a situation to an end, whether or not the breach transpires at the hands of a State.

\footnotetext{
* Professor, Faculty of Law, Monash University and Professor of International law, Wilberforce Institute, University of Hull, UK.
} 


\section{The Normative Content of the Prohibition of Slavery}

Historically, the movement to end slavery and the slave trade was premised on abolition: the repeal of laws allowing for the enslavement of persons. That is, 'to bring about the disappearance from written legislation ... of everything which admits the maintenance' of a person in slavery. ${ }^{1}$ To this end, States have met their negative obligations by repealing legislation allowing for slavery within their domestic jurisdictions. Yet, today, the normative content of slavery has been recognised as requiring more. This is so, as slavery in international law does not relate solely to the abolition of slavery, rather the norm has evolved to encompass the 'prohibition' of slavery.

While the 1926 Slavery Convention speaks of 'abolition',2 the 1956 Supplementary Convention on the Abolition of Slavery, the Slave Trade, and Institutions and Practices Similar to Slavery, despite its title, focuses on the prohibition of slavery, requiring the act of enslaving another person to be made a criminal offence. ${ }^{3}$ During the latter half of the $20^{\text {th }}$ century, the 'prohibition' of slavery would become part of general international law. In the first instance, Article 4 of the 1948 Universal Declaration of Human Rights states that '[n]o one shall be held in slavery or servitude; slavery and the slave trade shall be prohibited in all their forms'. In his 1996 study on the Universal Declaration, Hurst Hannum considered that:

the evidence of state practice uncovered in the course of research for this article suggests the following tentative conclusions with respect to the various articles of the Declaration...The prohibition against slavery in article 4 is... universally held to form part of customary law. ${ }^{4}$

The prohibition was codified into law in 1966 via Article 8 of the International Covenant on Civil and Political Rights which, as of the end of 2018, has 172 States Parties. ${ }^{5}$ These elements - the prohibition's inclusion in the Universal Declaration, the near universality of the Covenant - along with the acceptance of the prohibition as one of the peremptory norms of general international law, all speak to the prohibition of slavery being accepted as general international law. ${ }^{6}$

1 Viscount Cecil of Chelwood, 'Slavery Convention: Report Presented to the Assembly by the Sixth Committee' in League of Nations', Publications of the League of Nations: VI.B.1 Slavery (League of Nations, 1926), A.104.1926.VI.

2 Slavery Convention, signed 25 September 1926, 60 LNTS 254 (entered into force 9 March 1927) art 2 ('Slavery Convention').

3 See Supplementary Convention on the Abolition of Slavery, the Slave Trade, and Institutions and Practices Similar to Slavery, opened for signature 7 September 1956, 266 UNTS 3 (entered into force 30 April 1957) art 6(1) ('Supplementary Convention on the Abolition of Slavery').

4 Hurst Hannum, 'The Status of the Universal Declaration of Human Rights in National and International Law' (1996) 25 Georgia Journal of International and Comparative Law, 288, 342, 344 (emphasis added).

5 International Covenant on Civil and Political Rights, opened for signature 19

December 1966, 999 UNTS 171 (entered into force 23 March 1976).

6 See Vienna Convention on the Law of Treaties, opened for signature 23 May 1969, 1155 UNTS 331 (entered into force 27 January 1980) art 53 ('Vienna Convention on the Law of Treaties'). The International Law Commission has expressed the notion of a double opinio juris thus:

Article 53 of the 1969 Vienna Convention requires not merely that the norm in question should meet all the criteria for recognition as a norm of general international law, binding as such, but further that it should be recognized as having a peremptory character by the international community of States as a whole.

'Report of the International Law Commission on the Work of Its Fifty-Third Session (23 April - 1 June and 2 July - 10 August 2001)’ [2001] II(2) Yearbook of the International Law Commission 1, 85. 
Accepting that the 'prohibition' of slavery constitutes part of the normative content of slavery, as established in general international law, leads to a consideration of the meaning or content of such a 'prohibition'. According to the Oxford English Dictionary the ordinary meaning of the term to 'prohibit' is to 'forbid (an action, event, commodity, etc.) by a command, statute, law, or other authority; to interdict', ${ }^{7}$ while the word 'prohibition' is defined as 'the action or act of forbidding; an edict, decree, or order which forbids, prevents, or excludes'. 8

While there is a lack of an authoritative determination as to what constitutes a 'prohibition' in regard to slavery, guidance may be drawn as to the content of 'prohibition' from other norms which, like slavery, are also recognised as being peremptory and carrying obligations erga omnes: torture and genocide, though with the proviso that each of these norms have more explicit conventional provisions in regard to prevention. That said, the United Nations Committee Against Torture speaks of the 'absolute prohibition against torture' and that each State party must 'take actions that will reinforce the prohibition against torture through legislative, administrative, judicial, or other actions that must, in the end, be effective in preventing it'. ${ }^{9}$ For its part, the International Court of Justice has noted that the Convention on the Prevention and Punishment of the Crime of Genocide effectively creates a prohibition in regard to committing genocide. To that end, the International Court determined that the prohibition requires that States Parties both undertake 'not to commit the act so described' and to 'prevent the commission of acts of genocide'. ${ }^{10}$ Arguably, these considerations, when cast in regard to slavery, should also hold: that the norm prohibiting slavery requires States go beyond abolition and take positive action to prevent enslavement.

This appears to be the approach taken by the European Court of Human Rights ('European Court') in regard to the prohibition of slavery in the context where the European Convention on Human Rights itself is silent on an obligation to prevent. The European Court has made plain that States 'have positive obligations ... to adopt criminal-law provisions' in regard to the prohibition of slavery and 'to apply them in practice'. ${ }^{11}$ In its 2016 L.E. v Greece case, the European Court made those obligations more concrete, stating that 'it is penal law which constitutes the adequate recourse' in regard to the prohibition of slavery. ${ }^{12}$

Yet, despite this obligation to 'prohibit' slavery in general international law, almost half of all Members of the United Nations do not have criminal legislation prohibiting slavery. ${ }^{13}$ This also holds true for States party to the 1926 Slavery Convention, the 1956 Supplementary Convention on the Abolition of Slavery and the 1966 International Covenant on Civil and Political Rights. That is, with regard to each instrument, nearly half of these States Parties have yet to fulfil their treaty obligation in regard to the outlawing of slavery. Having stopped at abolition, via the repealing of laws, they have failed to actively introduce laws explicitly prohibiting slavery. This is so, in large part, because of a lingering contestation, noted earlier, as to the normative content of 'slavery'. The failure of a near majority of States Parties to

\footnotetext{
7 prohibit, $v$. Oxford English Dictionary, <http://www.oed.com.virtual.anu.edu.au/view/Entry/152255?rskey=WkpTEo\&result= 2\&isAdvanced=false\#eid $>$. 8 prohibition, $n$. Oxford English Dictionary: <http://www.oed.com.virtual.anu.edu.au/view/Entry/152258>.

9 United Nations Committee Against Torture, Convention Against Torture and Other Cruel, Inhuman or Degrading Treatment or Punishment General Comment No. 2: Implementation of Article 2 by States Parties, UN Doc. CAT/C/GC/2 (24 January 2008) [2].

10 Application of the Convention on the Prevention and Punishment of the Crime of Genocide (Bosnia and Herzegovina v Serbia and Montenegro) (Judgement) [2007] ICJ Rep 43, 74 [166].

11 Siliadin v France [2005] VII Eur Court HR 333, 363-364 [89].

12 L.E. v Greece, European Court of Human Rights, Application 71545/12, 21 January 2016, para. 121.

Translated from the French by the author.

13 See below fns 36-38.
} 
various instruments to move beyond abolition to prohibition is understandable as, during the $20^{\text {th }}$ century, a consensus held that the established definition of slavery in international law outlawed de jure slavery; it forbade the holding of a person, legally, in slavery. The logical outcome of such a reading of that definition was understood as a requirement to abolish — the repealing of laws on the books allowing slavery - rather than passing new laws prohibiting slavery.

In the wake of this consensus, what had transpired is the slow unravelling of the legal regime surrounding slavery during much of the $20^{\text {th }}$ century in favour of a reading that sought to capture the visceral capital inherent in the term 'slavery' at the expense of its legal definition. ${ }^{14}$ That definition, first set out in the 1926 Slavery Convention, reads: 'Slavery is the status or condition of a person over whom any or all of the powers attaching to the right of ownership are exercised'. ${ }^{15}$ From the 1930s onwards, a consensus grew at the international level that slavery went beyond its definition to be a concept which, it was said, included servitude and forced labour, and, over time, grew to also lay claim to such ills as apartheid, colonialism, incest, juvenile detention, migrant workers, and sex tourism. ${ }^{16}$ As historian Suzanne Miers noted in 2003, this expansive notion of slavery rendered the term 'virtually meaningless' ${ }^{17}$

However, at the turn of the $21^{\text {st }}$ century, a number of treaty provisions and judicial decisions coalesced to shine a new light on the normative content of the legal definition of 'slavery'. These include the conclusions of the 1998 Statute of the International Criminal Court, and the 2000 Protocol to Prevent, Suppress and Punish Trafficking in Persons, Especially Women and Children, Supplementing the United Nations Convention against Transnational Organized Crime. ${ }^{18}$ In 2002, the International Criminal Tribunal for the former Yugoslavia became the

14 See Jean Allain, 'The Legal Definition of Slavery into the Twenty-First Century' in Jean Allain (ed.), The Legal Understanding of Slavery: From the Historical to the Contemporary (Oxford University Press, 2012) 199.

15 Slavery Convention art 1(1) (emphasis added).

16 See David Weissbrodt and Anti-Slavery International, Contemporary Forms of Slavery: Updated review of the implementation of and follow-up to the conventions on slavery, 52nd sess, UN Doc E/CN.4/Sub.2/2000/3 (26 May 2000). In 2000, Weissbrodt sought to set out what practices were to be included in a conceptualisation of slavery: '[F]or the United Nations or any other international body to carry out a mandate concerned with slavery effectively, it is necessary to develop an international consensus on what practices are included within the concept of slavery' at 4, [7]. For Weissbrodt, those 'forms of slavery' included: serfdom, forced labour, debt bondage, exploitation of migrant workers, trafficking, prostitution, forced marriage and sale of wives, child labour and child servitude, etc at 5, [9].

17 Suzanne Miers, Slavery in the Twentieth Century: The Evolution of a Global Problem (AltaMira Press, 2003) 453.

18 Rome Statute of the International Criminal Court, opened for signature 17 July 1998, 2187 UNTS 90 (entered into force 1 July 2002) ('1998 Statute of the International Criminal Court'); Protocol to Prevent, Suppress and Punish Trafficking in Persons, Especially Women and Children, supplementing the United Nations Convention against Transnational Organized Crime, opened for signature 15 November 2000, 2237 UNTS 319 (entered into force 25 December 2003).

The 1998 Statute of the International Criminal Court establishes, at Article 7(1)(c), the crime against humanity of enslavement; at Article 7 (1) (g), the crime against humanity of sexual slavery (within a provision which reads: 'Rape, sexual slavery, enforced prostitution, forced pregnancy, enforced sterilization, or any other form of sexual violence of comparable gravity'); and, at Articles 8 (2)(b)(xxii) (international) and 8(2)(e)(vi) (non-international), the war crime of sexual slavery.

The definition of the crime of enslavement, as found at Article 7(2)(c), is also deemed the 'slavery' element of sexual slavery. That definition reads: "Enslavement" means the exercise of any or all of the powers attaching to the right of ownership over a person and includes the exercise of such power in the course of trafficking in persons, in particular women and children.'

The Protocol to Prevent, Suppress and Punish Trafficking in Persons, Especially Women and Children, Supplementing the United Nations Convention Against Transnational Organized Crime includes within its 
first international court to interpret the crime of enslavement. It was determined in the Kunarac case 'that the traditional concept of slavery, as defined in the 1926 Slavery Convention and often referred to as "chattel slavery", has evolved to encompass various contemporary forms of slavery which are also based on the exercise of any or all of the powers attaching to the right of ownership' 19 . However, in counter-distinction, the European Court of Human Rights found in its 2005 Siliadin judgment, that the same definition applied exclusively to cases of de jure slavery:

this definition corresponds to the 'classic' meaning of slavery as it was practiced for centuries. Although the applicant was, in the instant case, clearly deprived of her personal autonomy, the evidence does not suggest that she was held in slavery in the proper sense, in other words that Mr and Mrs B. exercised a genuine right of legal ownership over her, thus reducing her to the status of an 'object'. ${ }^{20}$

Here then was a classic example of international judicial bodies coming to divergent interpretations of a treaty provisions, in this instance, the definition of slavery. In such a situation where the general rules of treaty interpretation had left the meaning ambiguous, the 1969 Vienna Convention on the Law of Treaties speaks of, as a supplementary means of interpretation, recourse to the preparatory works of the instrument to seek to determine its meaning. ${ }^{21}$ The provision in question, the definition of slavery, was first set out in the 1926 Slavery Convention; ${ }^{22}$ it was also later reproduced, in substance, in both the 1956 Supplementary Convention on the Abolition of Slavery and the 1998 Statute of the International Criminal Court. ${ }^{23}$ The preparatory works or travaux préparatoires of the 1926 and 1956 Conventions were synthesised and published in 2008. ${ }^{24}$ That research assisted the High Court of Australia in determining that the 1926 definition was applicable both de jure, as well as de facto. As the High Court noted, this distinction was to be found in the first element of the definition, between 'status or condition':

Status is a legal concept. Since the legal status of slavery did not exist in many parts of the world, and since it was intended that it would cease to exist everywhere, the evident purpose of the reference to "condition" was to cover slavery de facto as well as de jure' ${ }^{25}$

definition of trafficking in persons, as found at Article 3(a), the requirement to address, inter alia, the trafficking for the purposes of exploitation by means of slavery. That definition reads:

"Trafficking in persons" shall mean the recruitment, transportation, transfer, harbouring or receipt of persons, by means of the threat or use of force or other forms of coercion, of abduction, of fraud, of deception, of the abuse of power or of a position of vulnerability or of the giving or receiving of payments or benefits to achieve the consent of a person having control over another person, for the purpose of exploitation. Exploitation shall include, at a minimum, the exploitation of the prostitution of others or other forms of sexual exploitation, forced labour or services, slavery or practices similar to slavery, servitude or the removal of organs.

19 Prosecutor $v$ Kunarac (Judgement) (International Criminal Tribunal for the former Yugoslavia, Appeals Chamber, Case Nos IT-96-23 and IT-96-23/1-A, 12 June 2002) 35.

20 Siliadin v France [2005] VII Eur Court HR 333, 369 [122].

21 Vienna Convention on the Law of Treaties, art 32.

22 Slavery Convention art 1(1).

23 Supplementary Convention on the Abolition of Slavery art 7(a); 1998 Statute of the International Criminal Court art 7(2)(c).

24 See Jean Allain, The Slavery Conventions: The Travaux Préparatoires of the 1926 League of Nations Convention and the 1956 United Nations Convention (Martinus Nijhoff Publishers, 2008).

25 The Queen v Tang (2008) 237 CLR 1, 17 [25]. See also Workers of Fazenda Brasil Verde v Brazil (Judgement, Preliminary Exceptions, Merits, Reparations and Costs) (2016) 318 Series C Inter-American Court of Human Rights 1, 71 [270], where it states: 'The first element (status or condition) refers to both the de jure and de facto 
In considering the second element of the definition, the exercise of those 'powers attaching to the right of ownership', the High Court found guidance in a 1953 United Nations Secretary General Report which spoke of: the ability to purchase or transfer a person; the absolute use of a person, their labour, or the ownership of the product of that labour; as well as the indeterminacy or the inheritability of the status or condition of a person held in slavery. ${ }^{26}$ While the High Court of Australia only engaged with these 'powers attaching to the right of ownership' to the extent required by the case at hand, it fell to academics and practitioners to provide further substance to what might constitute those powers when exercised against a person in a case of slavery. ${ }^{27}$ Their considerations resulted in the 2012 Bellagio-Harvard Guidelines of the Legal Parameters of Slavery which provided an interpretation of the definition of slavery which was meant to be both internally consistent with its property paradigm and also capture the lived experience of those who are enslaved. ${ }^{28}$

The breakthrough that this group achieved, that would later be recognised by the InterAmerican Court of Human Rights, was that fundamentally enslavement is about the exercise of control that one would recognise as possession in property law. That control, which is fundamental to ownership is articulated as 'possession'. It is the type of control which is required to establish slavery in law. That is: slavery is based on the exercise of the type of control tantamount to possession, as understood in property law. ${ }^{29}$ With this as a central building-block, the group then unlocked those 'powers attaching to the right of ownership', by recognising that where this background relationship of control of a person was tantamount to possession, then it followed that the other standard of incidents of ownership which Antony Honoré had developed in his seminal 1961 piece (to use, manage, profit, transfer and dispose) could be understood as those 'powers attaching to the right of ownership' constituting slavery. ${ }^{30}$

The Bellagio-Harvard Guidelines recognise that to determine a situation of slavery in law 'one must look for possession' ${ }^{31}$ Possession, being this background relationship of control, is fundamental to property law. To bridge the gap between property law and its application to instances of contemporary slavery, the Guidelines recognise that 'while the exact form of possession might vary, in essence it supposes control over a person by another such as a person might control a thing' ${ }^{32}$ What might that control look like? Such control is not incidental, rather fundamental: 'where such control operates, it will significantly deprive that person of his or her individual liberty for a period of time which is, for that person, indeterminate'. ${ }^{33}$

situation, i.e. the existence of a formal document or a legal standard for the characterization of this phenomenon is not essential, as in the case of chattel or traditional slavery'. Translated from the Spanish by the author.

26 United Nations Economic and Social Council, Report of the Secretary-General on Slavery, the Slave Trade, and Other Forms of Servitude, UN Doc E/2357 (27 January 1953) 36, n 1.

27 The Queen v Tang (2008) 237 CLR 1, 17 [25].

28 See Bellagio-Harvard Guidelines of the Legal Parameters of Slavery (2012) Queen's University Belfast <http://www.qub.ac.uk/schools/SchoolofLaw/Research/HumanRights/bellagio/>. The considerations of the Research Network which developed the Guidelines appears in Jean Allain (ed) The Legal Understanding of Slavery: From the Historical to the Contemporary (Oxford University Press, 2012).

29 A.M. Honoré, 'Ownership' in A. G. Guest (ed), Oxford Essays in Jurisprudence (Oxford University Press, 1961) 107, 113. In his classic study, Honoré states that possession is 'the foundation on which the whole superstructure of ownership rests', 113.

30 See generally Jean Allain and Robin Hickey, 'Property Law and the Definition of Slavery' (2012) 61 International and Comparative Law Quarterly 915-938.

31 Guideline 3-Possession is Foundational to Slavery, Bellagio-Harvard Guidelines of the Legal Parameters of Slavery, above n 28 .

32 Ibid.

33 Ibid. 
Quite simply, if a person is exercising control over another person in such a way that, if that control was over a thing, one would recognise it as ownership, then slavery is at hand.

The result of the development of this understanding of the relationship between property, law, and issues of slavery is captured by Guideline 2-The Exercise of the Powers Attaching to the Right of Ownership, in the following terms:

In cases of slavery, the exercise of 'the powers attaching to the right of ownership' should be understood as constituting control over a person in such a way as to significantly deprive that person of his or her individual liberty, with the intent of exploitation through the use, management, profit, transfer or disposal of that person. Usually this exercise will be supported by and obtained through means such as violent force, deception and/or coercion. $^{34}$

In 2016, this Guideline 2 was endorsed internationally by the Inter-American Court of Human Rights which cited it in order to establish its reading of the definition of slavery. In its 2016 Judgement, the Inter-American Court adopted the legal reasoning of the Guidelines noting that 'the concept of slavery in international law ... has evolved and is no longer limited to ownership over the person'. Rather the 'ownership' element of the definition:

must be understood in the phenomenon of slavery as 'possession', that is, the demonstration of control of one person over another. Therefore, 'when determining the level of control required to consider an act as slavery ... it could be equated with the loss of one's own will or a considerable reduction of personal autonomy'. In this sense, the so-called 'powers attaching to the right of ownership' must be understood in the present day as the control exercised over a person that significantly restricts or deprives him of his individual freedom with intent to exploit through the use, management, profit, transfer or disposal of a person. In general, this exercise will be supported and will be obtained through such means as violence, deception and/or coercion. ${ }^{35}$

The Guidelines themselves not only conceptualise slavery, they go on to demonstrate how slavery might be manifest through the various powers attaching to the right of ownership: use, management, benefit, transfer, or disposal of a person. Thus, in regard to what is often considered the sine qua non of enslavement, the buying or selling of a person (re: transfer of a person), Guideline 4(a) states, inter alia, that: 'Buying, selling or otherwise transferring a person may provide evidence of slavery. Having established control tantamount to possession; the act of buying, selling or transferring that person will be an act of slavery'. The Guidelines accept that buying, selling, or otherwise transfer, of a person is prima facie evidence of slavery. However, more is required than the appearance of buying or selling; such apparent buying or selling will not constitute slavery unless the background element of control is at play and the control is of such an intensity that were it in regard to a thing, one would recognise it as a property law manifestation of possession.

Consider the case of a football player transfer: the common parlance is to speak of a player being bought or sold. Yet it would be disingenuous and, in law incorrect, to speak of such a transfer constituting slavery (unless, of course, control tantamount to possession was being exercised over a player). In many ways the simple test is: can the person walk away; or is control being exerted in such a manner as to significantly deprive, in this situation, that player of not only her liberty of choice, but of her very liberty. While, for instance, forced labour will relate to the ability to compel work under duress in situations of employment; slavery goes

Guideline 2-The Exercise of the Powers Attaching to the Right of Ownership, Bellagio-Harvard Guidelines of the Legal Parameters of Slavery, (2012) Queen's University, Belfast

<http://www.qub.ac.uk/schools/SchoolofLaw/Research/HumanRights/bellagio/>.

35 Workers of Fazenda Brasil Verde v Brazil (Preliminary Objections, Merits, Reparations and Costs) (2016) 318 Series C, Inter-American Court of Human Rights 1, 71 [269], 71 [271] (citations omitted; translated from Spanish by the author). 
beyond the workplace environment, control being exercised over all facets of the life of the victim of enslavement.

The 2016 Judgment of the Inter-American Court of Human Rights confirms that the 2012 Bellagio-Harvard Guidelines of the Legal Parameters of Slavery provides guidance in applying the 1926 definition in a contemporary world where legal ownership of a person no longer exists. In so doing, the Inter-American Court, like the High Court of Australia in 2008, recognised that the 1926 definition is applicable to cases where a person is held in a condition of de facto slavery. As such, slavery is not to be understood as being exclusively about legally owning a person, rather it turns on controlling a person so as to negate, call it what you may: a person's agency, their autonomy, their freedom, or their liberty. It is the exerting of control tantamount to possession. With this understanding, the development of the 2012 BellagioHarvard Guidelines of the Legal Parameters of Slavery demonstrates the manner in which the internationally recognised definition of slavery is to be interpreted so as to be applicable in a world where legal enslavement has been abolished; by recognising that a person, beyond the legal, can be held in a condition of slavery. As a result of the determination of the InterAmerican Court of Human Rights, the latent power of the definition of slavery, developed through the Bellagio-Harvard Guidelines of the Legal Parameters of Slavery, is now recognised at the international level and, in its wake, the realisation that the obligations, including those erga omnes, undertaken by States in regard to the prohibition of slavery, having been for a long time considered hortatory, are now real.

\section{Legal Obligations Arising from the Prohibition of Slavery}

Having set out the parameters of what constitutes the definition of slavery, attention now turns to consider the legal obligations which flow from its prohibition. For most of the $20^{\text {th }}$ century, States assumed that the extent of their obligations in relation to slavery under applicable international law was to ensure its legal abolition, that is: the elimination of any existing possibility under domestic legislation that a person could exercise legal powers of ownership over another person. By contrast, the recognition, over the course of the early $21^{\text {st }}$ century, that the international law regarding slavery is applicable not only de jure but also de facto, mandates that obligations to prohibit slavery previously agreed to but never fulfilled must, as a matter of law, be undertaken. With this as a starting point, an examination of the obligations which States have undertaken via international treaty law will be set out as it relates to the 1926 Slavery Convention, the 1956 Supplementary Convention on the Abolition of Slavery, and the 1966 International Covenant on Civil and Political Rights. However, before those obligations are detailed, consideration turns first to detail the number of States which have failed to promulgate domestic legislation prohibiting slavery.

An examination of publicly available sources provides the possibility to consider the States Parties to the 1926 Slavery Convention, the 1956 Supplementary Convention on the Abolition of Slavery, and the 1996 International Covenant on Civil and Political Rights, so as determine which of these States have yet to legislate domestic criminal provisions prohibiting slavery as of the end of $2018 .{ }^{36}$ In regard to the 1926 Slavery Convention, 57 States of the 119 States

36 See Constitute Project, (2018) <https://www.constituteproject.org>; Jean Allain and Marie Lynch, Slavery in Domestic Legislation (October 2011) Queen's University Belfast < http://www.qub.ac.uk/slavery/>; Hans Engen, Special Rapporteur on slavery, Concise summary of the information supplied in accordance with resolutions 238 (IX), 276 (X), 388 (XIII), 475 (XV) and 525 A (XVII), UN ESCOR, 19th sess, Agenda Item 8, UN Doc E/2673 (9 February 1955; Mohamed Awad, Special Rapporteur on slavery, Report on slavery, UN Doc/E/4168/Rev.1 (1966). 
Parties to that instrument, or $47.2 \%$ of its States Parties, do not appear to have domestic criminal law provision; whereas $44.3 \%$ of the 124 States Parties to the 1956 Supplementary Convention on the Abolition of Slavery, or 55 States, lack domestic criminal law prohibiting slavery. ${ }^{37}$ Turning to the International Covenant on Civil and Political Rights, of its 172 States Parties, 81 States or $47.1 \%$ of the States Parties, lack domestic criminal legislation prohibiting slavery. ${ }^{38}$ In sum, of the 184 States bound by the above instruments, 88 States or $47.8 \%$ of States Parties have yet to carry out their treaty-based obligations to prohibit slavery by means of establishing criminal provisions within their respective domestic legal order.

This failure of more than 80 States to have in place domestic legislation explicitly criminalising slavery, robs the prohibition of its essence: the capacities of domestic criminal law systems to carry out the requirements which States have undertaken as a matter of international obligation in addressing cases of slavery within their own jurisdictions. ${ }^{39}$ While human rights instruments, be it the International Covenant on Civil and Political Rights or the regional human rights treaties, do not specifically mandate the criminalising of acts related to slavery; the 1926 Slavery Convention in regard to the slave trade and the 1956 Supplementary Convention on the Abolition of Slavery in regard to slavery, do so as a matter of international law. As for the International Covenant on Civil and Political Rights, it requires the adoption of legislative or other measures to give effect to its provisions, including those prohibiting slavery. ${ }^{40}$

Such a determination is limited by access to legislation in force. This is a result of legislation appearing in various languages, limited print runs, and internet accessibility. That said, the considerations presented here derive from an overall empirical study which considered 193 Member States of the United Nations (as well as Palestine); the extent to which they are party to the international instruments dealing with slavery, servitude, or forced labour; and then examining whether their domestic legislation covers such subject matter.

The study and its dataset were developed by the Working Group on Contemporary Slavery at Queen's University Belfast, which comprised Jean Allain (Chair), Andrew Chisholm, Amanda Kramer, Aisling Ledwith, Katarina Schwarz, and Egle Vasiliauskaite. It was later edited and further developed by Katarina Schwarz while at the University of Nottingham. The dataset is available upon request to the author at: jean.allain@monash.edu.

37 Note: The number of States which have consented to the 1926 Slavery Convention as indicated, include those party to the 1926 Slavery Convention, but also States party to the 1953 Protocol amending the Slavery Convention. The 1953 Protocol transfers the organisational elements of the 1926 Convention from the League of Nations to the United Nations.

38 In regard to both the 1956 Supplementary Convention on the Abolition of Slavery and the 1966 International Covenant on Civil and Political Rights, it should be noted that the State of Palestine is a State Party, though not a Member of the United Nations.

Where regional human rights systems are concerned, as of 31 December 2018, there are 54 States party to the African Charter on Human and Peoples' Rights, of which 22 States (41.5\%) appear to have no criminal domestic provisions in place prohibiting slavery. Regarding States within the Council of Europe, the numbers are as follows: of the 46 States Party to the European Convention on Human Rights, 21 States (45.7\%) are without criminal laws prohibiting slavery within their domestic legal order. Finally, within the Inter-American system, of the 23 States party to the American Convention on Human Rights, 14 States (60.9\%) do not appear to have legislation in place criminalising the prohibition of slavery.

39 See Nigel Rodley and Matt Pollard, 'Criminalisation of Torture: State Obligations Under the United Nations Convention Against Torture and Other Cruel, Inhuman or Degrading Treatment or Punishment' (2006) 1 European Human Rights Law Review 115, where the authors point to the value of the incorporation of domestic criminal law in regard to the prohibition of torture.

40 While supervisory bodies have not undertaken considerations as to whether their States Parties have in place domestic legislation prohibiting slavery, where the prohibition of torture is concerned, a limited number of States have sought to argue that there is no need to have provisions which explicitly prohibited 'torture', rather general provisions are sufficient. The Committee against Torture has seen things differently, noting in its General Comment Number 2 that the definition of torture as set out in the convention should be incorporated into domestic legislation, otherwise 'serious discrepancies between the Convention's definition and that incorporated into domestic law create actual or potential loopholes for impunity'. In considering the provisions of the International 
Turning now to consider the obligations flowing from the instruments prohibiting slavery; in regard to the 1926 Slavery Convention, it should be recognised that its penalties speak to the requirement 'to prevent and suppress the slave trade' rather than bringing about 'the complete abolition of slavery in all its forms'. Article 6 requires that States Parties 'whose laws do not at present make adequate provision for the punishment of infractions of laws and regulations ... adopt the necessary measures in order that severe penalties may be imposed in respect of such infractions'. ${ }^{41}$ The measures for which such penalties are to be imposed are found at Article 3, which reads, in part:

The High Contracting Parties undertake to adopt all appropriate measures with a view to preventing and suppressing the embarkation, disembarkation and transport of slaves in their territorial waters and upon all vessels flying their respective flags.

By contrast to the 1926 Slavery Convention, which speaks of the abolition of slavery but requires the prohibition of the slave trade, the 1956 Supplementary Convention on the Abolition of Slavery focuses on the prohibiting of slavery by reference to the criminal law:

The act of enslaving another person or of inducing another person to give himself or a person dependent upon him into slavery, or of attempting these acts, or being accessory thereto, or being a party to a conspiracy to accomplish any such acts, shall be a criminal offence under the laws of the States Parties to this Convention and persons convicted thereof shall be liable to punishment. ${ }^{42}$

Beyond this, the Supplementary Convention on the Abolition of Slavery requires, at its Article $3(1)$, that the involvement in the slave trade be penalised in domestic law:

Covenant on Civil and Political Rights, the Human Rights Committee echoes the same understanding, that ' $[t]$ he State party should explicitly prohibit torture ... by incorporating into its legislation a definition of torture that is fully in line with Article 7 of the Covenant'. See Human Rights Committee, Concluding observations on the fourth periodic report of Israel, 112th sess, 3127th mtg, UN Doc CCPR/C/ISR/CO/4 (21 November 2014) [14].

41 The fact that the provisions of the 1926 Slavery Convention regarding slavery relate to abolition - that is: the repealing of laws - is confirmed by the Viscount Cecil of Chelwood, the British Delegate, who reported the following to the Assembly of the League of Nations, in relation to the provisions specific to slavery of Article 2:

In a more general way, it interprets Article 2 as tending to bring about the disappearance from written legislation or from the custom of the country of everything which admits the maintenance by a private individual of rights over another person of the same nature as the rights which an individual can have over things.

See League of Nations, Slavery Convention: Report presented to the Assembly by the Sixth Committee, A.104.1926.VI, as found in League of Nations, Publications of the League of Nations, VI.B.Slavery.1926, VI.B.5, 24 September 1926, pp. 1-2.

42 See Article 6(1), Supplementary Convention on the Abolition of Slavery, the Slave Trade, and Institutions and Practices Similar to Slavery, opened for signature 7 September 1956, 266 UNTS 3 (entered into force 30 April 1957) art 6(1).

Also note the further requirement of Article 5:

In a country where the abolition or abandonment of slavery, or of the institutions or practices mentioned in article 1 of this Convention [re: debt bondage, serfdom, servile marriage, and child exploitation] is not yet complete, the act of mutilating, branding or otherwise marking a slave or a person of servile status in order to indicate his status, or as a punishment, or for any other reason, or of being accessory thereto, shall be a criminal offence under the laws of the States Parties to this Convention and persons convicted thereof shall be liable to punishment. 
The act of conveying or attempting to convey slaves from one country to another by whatever means of transport, or of being accessory thereto, shall be a criminal offence under the laws of the States Parties to this Convention and persons convicted thereof shall be liable to very severe penalties.

Where the International Covenant on Civil and Political Rights is concerned, Article 8(1) states that "no one shall be held in slavery; slavery and the slave-trade in all their forms shall be prohibited' ${ }^{43}$ As to the obligations which States have undertaken in regard to the prohibition of slavery, Article 2 mandates that States Parties 'respect and to ensure to all individuals ... the rights recognized in the present Covenant'; and to that end:

Where not already provided for by existing legislative or other measures, each State Party to the present Covenant undertakes to take the necessary steps, in accordance with its constitutional processes and with the provisions of the present Covenant, to adopt such legislative or other measures as may be necessary to give effect to the rights recognized in the present Covenant.

In considering, specifically, the obligation to give effect to the rights within the ambit of Article 2, the Human Rights Committee (the monitoring body of the of the International Covenant on Civil and Political Rights) has stated that 'unless Covenant rights are already protected by their domestic laws or practices, States Parties are required on ratification to make such changes to domestic laws and practices as are necessary to ensure their conformity with the Covenant'. ${ }^{44}$

\section{Obligations Arising Erga Omnes Partes}

Beyond those reciprocal obligations which are the foundation of contemporary international law, the 2001 Draft Articles on the Responsibility of States for Internationally Wrongful Acts ('Articles on State Responsibility') ${ }^{45}$ recognise communitarian threads in the law which extend beyond the bilateral. These are two-fold and are expressed as obligations erga omnes: those obligations of a State owed to the international community as a whole; and obligations erga omnes partes: those obligations of a State owed to a group of States where the protection of a collective interest is at play. ${ }^{46}$ In essence, an obligation arising erga omnes partes, for our purposes, allows a State Party, to an instrument dealing with the prohibition of slavery which

\footnotetext{
43 At the regional level, Article 5 of the 1981 African Charter on Human and Peoples' Rights reads, in part: 'All forms of exploitation and degradation of man, particularly slavery, slave trade, torture, cruel, inhuman or degrading punishment and treatment shall be prohibited' (emphasis added). As for the 1969 American Convention on Human Rights, it establishes, at Article 6(1), that '[n]o one shall be subject to slavery or to involuntary servitude, which are prohibited in all their forms ...' (emphasis added); while Article 4(1) of the European Convention on Human Rights, entitled the 'Prohibition of slavery and forced labour' reads: 'no one shall be held in slavery or servitude'(emphasis added).

44 Human Rights Committee, General Comment No. 31 [80]: The Nature of the General Legal Obligation Imposed on States Parties to the Covenant, 80th sess, 2187th mtg, UN Doc CCPR/C/21/Rev.1/Add. 13 (26 May 2004) [13].

45 See 'Report of the International Law Commission on the Work of Its Fifty-Third Session (23 April - 1 June and 2 July - 10 August 2001)' [2001] II(2) Yearbook of the International Law Commission 1.

46 See Responsibility of States for internationally wrongful acts, GA Res 56/83, UN GAOR, 56th sess, 85th plen mtg, Agenda Item 162, UN Doc A/RES/56/83 (12 December 2001) annex art 48(1), which reads, in part:
}

Any State other than an injured State is entitled to invoke the responsibility of another State ... if: (a) the obligation breached is owed to a group of States including that State, and is established for the protection of a collective interest of the group. 
is not directly injured by a breach of another State Party to invoke its responsibility. The Institute of International Law speaks of erga omnes partes in the following terms, as:

an obligation under a multilateral treaty that a State party to the treaty owes in any given case to all the other States parties to the same treaty, in view of their common values and concern for compliance, so that a breach of that obligation enables all these States to take action. 47

The prohibition of slavery creates a fundamental obligation for States Parties to such instruments to have in place domestic criminal legislation giving voice to this prohibition. As has been noted, despite this obligation - which will shortly be shown to be erga omnes partes - almost half of all States Parties considered above are yet to include in their domestic legal order criminal provisions which speak to their treaty obligations regarding the prohibition of slavery.

In general terms, the legal consequences of an ordinary breach of international law is that a State committing the wrongful act must cease, provide assurances and guarantees of nonrepetition, and make full reparations for the injury caused. ${ }^{48}$ Leaving aside the 1926 Slavery Convention which speaks of the abolition of slavery, the 1956 Supplementary Convention on the Abolition of Slavery would ordinarily allow an injured State to invoke the responsibility of a State by way of the compromissory clause of this instrument. ${ }^{49}$ However, in regard to the failure of a State to pass domestic legislation, a question may be raised as to which third State, if any, could claim to be injured by such an omission of legislation? The answer to that question will become evident in what follows, as the 1956 Supplementary Convention on the Abolition of Slavery arguably generates obligations erga omnes partes, allowing any other State Party to that instrument to invoke responsibility.

By regarding the prohibition of slavery generating obligations erga omnes partes, the International Law Commission has, in effect, set out two conditions for such obligations to come into play. They are, first: that the invocation of responsibility must be owed to the States Parties of the treaty in question; and second, that 'the obligation must have been established for the protection of a collective interest'. In the case of the 1956 Supplementary Convention on the Abolition of Slavery, despite the instrument having been conceived on the basis of reciprocal bilateralism, it can be argued that a collective interest in relation to slavery has emerged which generates, within the instrument, obligations erga omnes partes. This is possible, as the Commission notes that the provision related to protecting the collective interest 'does not distinguish between different sources of international law; obligations protecting a collective interest of the group may derive from multilateral treaties or customary international law'. ${ }^{50}$ In the case at hand, with the 1956 Supplementary Convention on the Abolition of Slavery silent on the matter, the prohibition of slavery allowing for a collective interest to be invoked

47 Institut de Droit International (Fifth Commission), 'Obligations and rights erga omnes in international law' (Krakow Session - 2005), art 1 (b)

48 See Responsibility of States for internationally wrongful acts, GA Res 56/83, UN GAOR, 56th sess, 85th plen mtg, Agenda Item 162, UN Doc A/RES/56/83 (12 December 2001) annex arts 28-31.

49 See Supplementary Convention on the Abolition of Slavery, the Slave Trade, and Institutions and Practices Similar to Slavery, opened for signature 7 September 1956, 266 UNTS 3 (entered into force 30 April 1957) art 10:

Any dispute between States Parties to this Convention relating to its interpretation or application, which is not settled by negotiation, shall be referred to the International Court of Justice at the request of any one of the parties to the dispute, unless the parties concerned agree on another mode of settlement.

50 Report of the International Law Commission, UN GAOR, 56th sess, Supp No 10, UN Doc A/56/10 (2001) 320. 
in its protection could, arguably, be derived from its international customary law basis, flowing from the recognition of the prohibition in general international law as both a peremptory norm and - as we shall see shortly — carrying obligations erga omnes.

What then is the nature of those collective interests which the International Law Commission speaks to as a condition for invoking obligations erga omnes partes? The Commission makes reference to interests in regard to the environment, security, and human rights. Turning to the latter, it notes that 'this would include situations in which States, attempting to set general standards of protection for a group or people, have assumed obligations protecting non-State entities' ${ }^{51}$ Where the 1956 Supplementary Convention on the Abolition of Slavery is concerned, although established before the coming into existence of a fully-fledged international human rights law, it can be argued that the customary nature of the prohibition of slavery, having been recognised as a peremptory norm of international law creates, amongst the Parties to the 1956 Supplementary Convention on the Abolition of Slavery, obligations erga omnes partes. While such an argument is plausible, it is by no means certain, as the Convention is a criminal law, rather than a human rights law, instrument; while the source of the collective interests generated by the prohibition of slavery is custom based, rather than flowing specifically from the 1956 Supplementary Convention on the Abolition of Slavery.

A rather stronger case for the prohibition of slavery generating obligations erga omnes partes, can be made in regard to the International Covenant on Civil and Political Rights, as it fits more comfortably within the framework of the conditions set out by the International Law Commission: the acknowledged collective interest to be found in the International Covenant on Civil and Political Rights which sets 'general standards of protection for a group or people'. Further, the added-value in focusing on the 1966 International Covenant on Civil and Political Rights and its obligations erga omnes partes is that it captures nearly 50 more States Parties than the 1956 Supplementary Convention on the Abolition of Slavery.

In regard to the International Covenant on Civil and Political Rights, can it be said, as a condition of the International Law Commission for establishing obligations erga omnes partes, that its obligations were 'established for the protection of a collective interest'? In general, various international human rights courts have spoken of this collective interest in protecting the individual, noting, in essence, that: 'States can be deemed to submit themselves to a legal order within which they, for the common good, assume various obligations, not in relation to other States, but towards all individuals within their jurisdiction'. ${ }^{52}$ The prohibition of slavery has established a firm foundation in international human rights law that goes beyond the simple normative requirement to abolish slavery. As a result of its inclusion in universal and regional human rights instruments meant to protect the collective interest of individuals, which provide, inter alia, for the protection from slavery, it may be said that flowing from the prohibition of slavery are obligations erga omnes partes.

In the case of the International Covenant on Civil and Political Rights, the Human Rights Committee has recognised that the obligations of Article 2 are indeed obligations erga omnes partes:

While article 2 is couched in terms of the obligations of State Parties towards individuals as the right-holders under the Covenant, every State Party has a legal interest in the performance by every other State Party of its obligations. This follows from the fact that the 'rules concerning the basic rights of the human person' are erga omnes obligations and that, as indicated in the fourth preambular paragraph of the Covenant, there is a United Nations Charter obligation to promote universal respect for, and observance of, human rights and

\footnotetext{
51 Ibid 320-321.

52 The Effect of Reservations on the Entry into Force of the American Convention on Human Rights (InterAmerican Court of Human Rights, Advisory Opinion OC-2/82, 24 September 1982) [29].
} 
fundamental freedoms. Furthermore, the contractual dimension of the treaty involves any State Party to a treaty being obligated to every other State Party to comply with its undertakings under the treaty. 53

Thus, each State party to the International Covenant on Civil and Political Rights has a legal interest in ensuring that every other State Party fulfils its obligations, erga omnes partes.

For its part, the International Court of Justice has had the opportunity to consider the nature of obligations erga omnes partes in a case related to the former President of Chad, Hissène Habré, as it pertains to the 1984 Convention against Torture and Other Cruel, Inhuman or Degrading Treatment or Punishment. In the Questions relating to the Obligation to Prosecute or Extradite case between Belgium and Senegal, the International Court considered 'whether being a party to the Convention is sufficient for a State to be entitled to bring a claim to the Court concerning the cessation of alleged violations by another State party of its obligations', when the State bringing the claim was not specifically injured. The Court determined that the States Parties to the Convention against Torture and Other Cruel, Inhuman or Degrading Treatment or Punishment had 'a common interest to ensure, in view of their shared values, that acts of torture are prevented' and that this 'common interest implies that the obligations in question are owed by any State party to all the other States Parties to the Convention'. Citing the Barcelona Traction case, the International Court of Justice stated that 'all the States Parties "have a legal interest" in the protection of the rights involved' and that '[ $t$ ]hese obligations may be defined as "obligations erga omnes partes" in the sense that each State party has an interest in compliance with them in any given case'. The International Court then went on to consider the common interest in more detail:

The common interest in compliance with the relevant obligations under the Convention against Torture implies the entitlement of each State party to the Convention to make a claim concerning the cessation of an alleged breach by another State party. If a special interest were required for that purpose, in many cases no State would be in the position to make such a claim. It follows that any State party to the Convention may invoke the responsibility of another State party with a view to ascertaining the alleged failure to comply with its obligations erga omnes partes, ... and to bring that failure to an end. 54

Although speaking of obligations flowing from the Convention against Torture and Other Cruel, Inhuman or Degrading Treatment or Punishment, by analogy, it may be said that this reading by the International Court of Justice in regard to the prohibition of torture would apply in regard to obligations erga omnes partes to the prohibition of slavery, mutatis mutandis. The legal interest being protected is of the same fundamental nature as the prohibition of slavery, as the International Court recognised later in the case that 'the prohibition of torture is part of customary international law and it has become a peremptory norm (jus cogens) '. ${ }^{55}$ While the Human Rights Committee notes that States Parties owe obligations erga omnes partes as they relate to all rights contained within the International Covenant on Civil and Political Rights, the International Court of Justice appears to recognise that the application of obligations erga omnes partes relates to the nature of the legal right involved: that obligations erga omnes partes flow from the prohibition of torture as a jus cogens norm. If this reading is correct, then not only are obligations erga omnes partes at play in regard to the prohibition of slavery within the International Covenant on Civil and Political Rights, but because of the nature of the interests to be protected, such obligations may be invoked in respect of other instruments prohibiting

53 Human Rights Committee, General Comment No. 31 [80]: The Nature of the General Legal Obligation Imposed on States Parties to the Covenant, 80th sess, 2187th mtg, UN Doc CCPR/C/21/Rev.1/Add. 13 (26 May 2004) [2].

54 Questions relating to the Obligation to Prosecute or Extradite (Belgium v. Senegal) (Judgment) [2012] ICJ Rep 422 [68]-[69].

55 Ibid [99]. 
slavery. These would include not only the 1956 Supplementary Convention on the Abolition of Slavery, but also other international instruments, to the extent of the prohibition of slavery as set out in, for instance, regional human rights treaties, the 2000 Protocol to Prevent, Suppress and Punish Trafficking in Persons Especially Women and Children, supplementing the United Nations Convention against Transnational Organized Crime, or the 1999 International Labour Organization Convention concerning the Prohibition and Immediate Action for the Elimination of the Worst Forms of Child Labour. It would further apply to the 1926 Slavery Convention, in regard to the slave trade.

The result of these considerations is that all States Parties to an instrument which prohibits slavery - including those States not directly injured by a breach by another State Party have the right, in law, to invoke an obligation erga omnes partes where there is breach of the prohibition. While one's first thought might turn to the act of enslaving a person as the breach of the prohibition of slavery; this section has considered the omission of nearly half of all States to have in place domestic criminal legislation as entailing their responsibility and the resulting possibility for any States Party to invoke an obligation erga omnes partes as a means of remedying such breaches of the prohibition of slavery.

\section{Obligations Arising Erga Omnes}

It should be recognised that beyond treaty-based obligations erga omnes partes, under customary international law the prohibition of slavery caries obligations arising erga omnes. The contemporary case of the enslavement of Yazidi girls and women will now be considered as a vehicle to examine more broadly this concept of obligations erga omnes, in relation to a violation of the prohibition of slavery. What transpired in northern Iraq starting in 2014, and continued in 2018 for more than 1,500 girls and women, is of the magnitude which would ordinarily bring into play further elements of the regime of State Responsibility in respect to obligations owed, in this case, to the international community as a whole. This is so, as 'serious breaches of obligations arising under peremptory norms of general international law', such as those related to the prohibition of slavery, in the case at hand 'can attract additional consequences, not only for the responsible State but for all other States'. ${ }^{56}$

That said, what will become apparent is that the mass enslavement of Yazidi girls and women at the hands of the Islamic State of Iraq and Al-Sham raises fundamental questions as to the value of obligations erga omnes as it relates specifically to the prohibition of slavery. The questions raised are not only in regard to the commission of serious violations by a nonState entity, but also whether one can envision a scenario in which mass enslavement could transpire, either at the hands of a State or a non-State actor, in isolation from other serious violations of international law? The latter question is pertinent as the actions of ISIS - the mass violation of the prohibition of slavery - is but one of many fundamental breaches of international law documented by the Commission of Inquiry on the Syrian Arab Republic and recognised by the United Nations Security Council, including genocide, war crimes, and crimes against humanity. ${ }^{57}$ Before considering this question, attention will, by necessity, turn to the

56 Report of the International Law Commission, UN GAOR, 56th sess, Supp No 10, UN Doc A/56/10 (2001) 281-282.

Note also the provisions in regard to serious breaches obligations arising under peremptory norms of general international law as they relate to international organisation as set out in Articles 41 and 42 of the Articles on the Responsibility of International Organizations. United Nations, International Law Commission, Yearbook of the International Law Commission, Volume II, 2011, UN Doc. A/66/10, 62.

57 Human Rights Council, "They came to destroy": ISIS Crimes Against the Yazidis, 32nd sess, Agenda Item 4, UN Doc A/HRC/32/CRP.2 (15 June 2016) 6. 
enslavement of Yazidi girls and women, so as to provide the platform to engage with the concept of obligations erga omnes.

The Independent International Commission of Inquiry on the Syrian Arab Republic, established by the United Nations Human Rights Council, released a report in 2016 which noted that 2 August 2014 was a day like any other for the Yazidis of Sinjar, northern Iraq; but that 'within 24 hours, their lives would become unrecognisable to them. The date of 3 August 2014 would become a dividing line, demarcating when one life ended, and - for those who survived - when another, infinitely more cruel, existence began'. ${ }^{58}$ In 2014, ISIS had become a de-facto State with effective control over a large swath of northern Iraq and Syria. Within its self-styled Caliphate, ISIS revived the slave-trade as being legitimate, finding Koranic justification for what it acknowledged itself as being 'large-scale enslavement'; declaring that: 'after capture, the Yazidi women and children were then divided according to the Shariah amongst the fighters of the Islamic State who participated in the Sinjar operations'. ${ }^{59}$ This rather banal description of what transpired within the shadow of Mount Sinjar, the holy land of the Yazidi, a Kurdish religious minority, belies the survivors' testimony, which is harrowing. ${ }^{60}$

The Commission of Inquiry notes that when the villages of the Sinjar region where overrun by ISIS, boys and men were separated from girls and women. ${ }^{61}$ In a number of instances, there were summary executions of all males; in other cases, the boys and men were obliged to convert to Islam on pain of death then forcibly put to work. ${ }^{62}$ It is estimated that thousands of Yazidi girls and women were then transported to holding sites around Mosul. ${ }^{63}$ At one of these locations a mass killing of women over the age of sixty took place. ${ }^{64}$ For the girls and women that remained, it was in those holding sites that they became human chattels-slaves to be selected by ISIS fighters as war booty. As the Commission of Inquiry emphasised, there were no incidents of mass rape at any of these holding sites, 'despite the fact that hundreds of girls and women were held captive at the sites, surrounded by dozens of young, armed men'. ${ }^{65}$ This was so, as the sexual violence and slavery visited upon the Yazidi girls and women, transpired only within the ideological framework established by ISIS in its reintroduction of the slave

\footnotetext{
58 Ibid.

59 Islamic State of Iraq and the Levant, 'Revival of Slavery before the Hour', Dabiq, Volume 4, $2014,15$.

60 See, eg, Amnesty International, Escape from Hell: Torture and Sexual Slavery in Islamic State Captivity in Iraq (2014) <https://www.amnesty.org.uk/files/escape_from_hell__torture_and_sexual_slavery_in_islamic_state_captivity_in_iraq_-_english_2.pdf >; Human Rights Watch, 'Iraq: Women Suffer under ISIS' (5 April 2016) <https://www.hrw.org/news/2016/04/05/iraq-women-sufferunder-isis>.

61 Human Rights Council, "They came to destroy": ISIS Crimes Against the Yazidis, 32nd sess, Agenda Item 4, UN Doc A/HRC/32/CRP.2 (15 June 2016) 8.

62 Ibid 8-9.

63 Ibid 7.

64 Ibid 11. Note also the following which speaks to abductions rather than enslavement:
}

On 3 June, the Department of Yazidi Affairs in the Ministry of Awqaf and Religious Affairs of the Kurdistan Regional Government reported that, of the 6,417 Yazidis (3,548 female and 2,869 male) abducted by ISIL since August 2014, fewer than half had been freed or escaped. On the same day, the Department also reported that 3,117 Yazidis (1,452 female and 1,665 male) remained in ISIL captivity or were missing.

Implementation of resolution 2367 (2017) — Report of the Secretary-General, UN Doc S/2018/677 (9 July 2018) 9 .

65 Human Rights Council, "They came to destroy": ISIS Crimes Against the Yazidis, 32nd sess, Agenda Item 4, UN Doc A/HRC/32/CRP.2 (15 June 2016) 12. 
trade. That is, that the forced labour, rape, and violence used was the legal prerogative of 'those who "own" the girls and women'. ${ }^{66}$ The Commission of Inquiry notes that:

Captured Yazidi girls and women are deemed property of ISIS and are openly termed sabaya or slaves. ISIS made eighty percent of the girls and women available to its fighters for individual purchase, the apportioning being drawn directly from religious interpretation. ISIS sells Yazidi girls and women in slave markets, or souk sabaya, or as individual purchases to fighters who come to the holding centres. In some instances, an ISIS fighter might buy a group of Yazidi females in order to take them into rural areas without slave markets where he could sell them individually at a higher price. The remaining twenty percent are held as collective property of ISIS and were distributed in groups to military bases throughout Iraq and Syria. ${ }^{67}$

It was a common occurrence for Yazidi girls and women to be sold numerous times. Within a year, ISIS fighters 'had started to hold online slave auctions', and slave markets were common, organised by the central 'Committee for the Buying and Selling of Slaves'. ${ }^{68}$ These were truly slave auctions, where in certain instances teeth were checked and the Yazidi were made to walk on a 'catwalk', through a large room of ISIS fighters, where they were sold to the highest bidder. ${ }^{69}$ The Yazidi women and girls who were enslaved were very much treated as property as regulated within the Caliphate. Where a Yazidi woman or girl's 'fighter-owner died intestate, she reverted to being the collective property of ISIS, with the local Wali charged with organising her resale' ${ }^{70}$ Further, as the Yazidi were considered spoils of war, they were not permitted to be resold to non-ISIS members. Such sales were deemed to be 'punishable by death' ${ }^{71}$ Here then was a mass violation of the prohibition of slavery which should attract obligations erga omnes.

First given legal currency by the International Court of Justice in the 1970 Barcelona Traction case, obligations erga omnes are those obligations which a State owes to the international community as a whole. In what is recognised as its most famous obiter dictum, the Court, in adjudicating a case involving the invocation of diplomatic protection of foreign shareholders for the failed venture of the Barcelona Traction, Light and Power Company, had the following to say:

33. When a State admits into its territory foreign investments or foreign nationals, whether natural or juristic persons, it is bound to extend to them the protection of the law and assumes obligations concerning the treatment to be afforded them. These obligations, however, are neither absolute nor unqualified.

The International Court of Justice then went on to say:

In particular, an essential distinction should be drawn between the obligations of a State towards the international community as a whole, and those arising vis-à-vis another State in the field of diplomatic protection. By their very nature the former are the concern of all States. In view of the importance of the rights involved, all States can be held to have a legal interest in their protection; they are obligations erga omnes.

34. Such obligations derive, for example, in contemporary international law, from the outlawing of acts of aggression, and of genocide, as also from the principles and rules concerning the basic rights of the human person, including protection from slavery and racial discrimination. Some of the corresponding rights of protection have entered into the body of general international law (Reservations to the Convention on the

${ }^{66}$ Human Rights Council, "They came to destroy": ISIS Crimes Against the Yazidis, 32nd sess, Agenda Item 4, UN Doc A/HRC/32/CRP.2 (15 June 2016) 11-12.

67 Ibid 12.

68 Ibid 13.

69 Ibid.

70 Ibid 13-14.

71 Ibid 13-15. 
Prevention and Punishment of the Crime of Genocide, Advisory Opinion, I.C.J. Reports 1951, p. 23); others are conferred by international instruments of a universal or quasi-universal character. ${ }^{72}$

Slavery, along with racial discrimination, are the two examples the Court provides of those 'principles and rules concerning the basic rights of the human person' which benefit from the protection of obligations erga omnes..$^{73}$ In taking up this pronouncement in its 2001 Articles on State Responsibility, the International Law Commission notes that 'the Court's statement clearly indicates that for the purposes of State responsibility certain obligations are owed to the international community as a whole', and that by reason of 'the importance of the rights involved, all States have a legal interest in their protection' ${ }^{74}$

As the prohibition of slavery can generate obligations erga omnes, this implies that any State may invoke the responsibility of another State whether or not it has been specifically injured by such a breach. This is most pertinent in regard to the ten States which are currently bound exclusively by general international law, as they carry no treaty obligations flowing from the following treaties which speak to the prohibition of slavery: to the 1926 Slavery Convention, 1956 Supplementary Convention on the Abolition of Slavery, or the 1966 International Covenant on Civil and Political Rights. ${ }^{75}$ These states are Bhutan, Brunei Darussalm, Kiribati, the Federated States of Micronesia, Oman, Saint Kitts and Nevis, South Sudan, Tonga, Tuvalu, and the United Arab Emirates. In regard to these States, invocation in regard to violations of the prohibition of slavery by third States could be made on the basis of customary international law flowing from erga omnes obligations. Article 48(1)(b) of the 2001 Articles on States Responsibility speaks to invoking responsibility by a State other than an injured State, wherein 'the obligation breached is owed to the international community as a whole'. ${ }^{76}$ This provision

72 Barcelona Traction, Light and Power Company Ltd (Belgium v Spain) (Judgment) [1970] ICJ Rep 3, [33], [34]. Note also [91], though seldom mentioned, refers back to [34]:

With regard more particularly to human rights, to which reference has already been made in paragraph 34 of this Judgment, it should be noted that these also include protection against denial of justice. However, on the universal level, the instruments which embody human rights do not confer on States the capacity to protect the victims of infringements of such rights irrespective of their nationality. It is therefore still on the regional level that a solution to this problem has had to be sought; thus, within the Council of Europe, of which Spain is not a member, the problem of admissibility encountered by the claim in the present case has been resolved by the European Convention on Human Rights, which entitles each State which is a party to the Convention to lodge a complaint against any other contracting State for violation of the Convention, irrespective of the nationality of the victim.

73 For considerations as to why slavery and racial discrimination were the rights highlighted by the International Court of Justice, see Jean Allain, 'Decolonisation as the Source of the Concepts of Jus Cogens and Obligations Erga Omnes' in Zeray Yihdego, Melaku Geboye Desta and Fikremarkos Merso (eds), Ethiopian Yearbook of International Law (Springer, 1st ed, 2017) 35.

74 'Report of the International Law Commission on the Work of Its Fifty-Third Session (23 April - 1 June and 2 July - 10 August 2001)' [2001] II(2) Yearbook of the International Law Commission 1, 111.

75 International Covenant on Civil and Political Rights, opened for signature 19 December 1966, UNTS 999 (entered into force 23 March 1976).

76 'Report of the International Law Commission on the Work of Its Fifty-Third Session (23 April - 1 June and 2 July - 10 August 2001)' [2001] II(2) Yearbook of the International Law Commission 1, 126. art 48 (Invocation of responsibility by a State other than an injured State) reads, in part:

1. Any State other than an injured State is entitled to invoke the responsibility of another State in accordance with paragraph 2 if: ... (b) the obligation breached is owed to the international community as a whole.

2. Any State entitled to invoke responsibility under paragraph 1 may claim from the responsible State:

(a) cessation of the internationally wrongful act, and assurances and guarantees of non-repetition in accordance with article 30; and 
of the Articles on States Responsibility, the International Law Commission noted, was intended 'to give effect to the statement by the ICJ in the Barcelona Traction case', wherein the International Court of Justice noted that 'all States can be held to have a legal interest in the fulfilment of these rights'. ${ }^{77}$

For its part, Article 48(2) of the 2001 Articles on States Responsibility sets out what obligations, owed to the international community as a whole, may be invoked by a State other than an injured State. Where there is a violation, a third State may call on the State in breach of a norm, such as the prohibition of slavery, to: cease the wrongful act; provide assurances and guarantees of non-repetition; and repair the damage vis the aggrieved party. ${ }^{78}$

Before consider the formal invoking of the regime envisioned by the Articles on State Responsibility in regard to obligations erga omnes, it is worthwhile noting the diplomatic avenues set out by the International Law Commission in regard to action falling short of the invocation of State Responsibility:

\begin{abstract}
A State does not invoke the responsibility of another State merely because it criticizes that State for a breach and calls for observance of the obligation, or even reserves its rights or protests. For the purpose of these articles, protest as such is not an invocation of responsibility; it has a variety of forms and purposes and is not limited to cases involving State responsibility. There is in general no requirement that a State which wishes to protest against a breach of international law by another State or remind it of its international responsibilities in respect of a treaty or other obligation by which they are both bound should establish any specific title or interest to do so. Such informal diplomatic contacts do not amount to the invocation of responsibility unless and until they involve specific claims by the State concerned, such as for compensation for a breach affecting it, or specific action such as the filing of an application before a competent international tribunal, or even the taking of countermeasures. ${ }^{79}$
\end{abstract}

As such, any State may protest or remind another State of 'its international responsibilities', in regard to obligations to prohibit slavery. This diplomatic avenue would appear to be a first port of call for any State where another State appears to be in breach of its international obligation to prohibit slavery, whether this be custom- or treaty-based. ${ }^{80}$

Beyond these diplomatic avenues, the formal invoking of the regime envisioned by the Articles on State Responsibility by a State acting on those legal interests owed to the international community may transpire via access to a 'competent international tribunal', or through 'countermeasures' ${ }^{81}$ As regards access to a competent international tribunal, Christian Tams has noted in the conclusion to his treatise on the enforcing of obligations erga omnes,

(b) performance of the obligation of reparation in accordance with the preceding articles, in the interest of the injured State or of the beneficiaries of the obligation breached. ...

77 Ibid 126.

78 Ibid. This being a separate question from an individual's the right to a remedy as a victim of such violations.

79 Ibid 117.

80 In this same vein, the Human Rights Committee has noted that beyond invoking formal procedures of the International Covenant on Civil and Political Rights, State Parties could act:

To draw attention to possible breaches of the Covenant obligations by other States Parties and to call on them to comply with their Covenant obligations should, far from being regarded as an unfriendly act, be considered as a reflection of legitimate community interests.

Human Rights Committee, General Comment No. 31: The Nature of General Legal Obligations Imposed on States Parties to the Covenant, 18th sess, UN Doc CCPR/C/21/Rev.1/Add. 13 (26 May 2004) [2].

81 Stefan Talmon, 'The Duty Not to 'Recognize as Lawful' a Situation Created by the Illegal Use of Force or Other Serious Breaches of a Jus Cogens Obligation: an Obligation without Real Substance?' in Christian Tomuschat and Jean-Marc Thouvenin (eds), The Fundamental Rules of the International Legal Order: Jus Cogens and Obligations Erga Omnes (Brill | Nijhoff, 2005) 99, 117. 
that the jurisprudence of the International Court of Justice since 1970 'on obligations erga omnes provides considerable support for a broad interpretation of the Barcelona Traction dictum pursuant to which all States have standing in ICJ disputes involving obligations erga omnes'.82 That said, Professor Tams continues with the fundamental proviso: 'Where jurisdiction is established'. ${ }^{83}$ Where such jurisdiction is established, 'all States can institute proceedings against States principally responsible for violations of obligations erga omnes' ${ }^{84}$ In this regard, where the International Court of Justice is concerned, beyond the Optional Clause system, it might be noted that both the 1926 Slavery Convention (via a 1953 Protocol) and the 1956 Supplementary Convention on the Abolition of Slavery, the Slave Trade, and Institutions and Practices Similar to Slavery have compromissory clauses, which ultimately provide the International Court of Justices with jurisdiction in regard to the prohibition against slavery. ${ }^{85}$ More narrowly, where issues of jus cogens are specifically at play in the invalidation of treaties, the Vienna Convention on the Law of Treaties, at Article 66, also provides the possibility for invoking the jurisdiction of the International Court of Justice. ${ }^{86}$

Where a State does not have standing before international judicial fora or chooses not to engage in such proceedings, the second option mentioned by the International Law Commission, that of self-help via countermeasures could be invoked in regards to obligations erga omnes. This possibility established within the Articles on State Responsibility raises the question as to whether a State, not specifically injured, may take countermeasures in an attempt to have the responsible State cease a breach of an obligation erga omnes. ${ }^{87}$ The Commentary provided by the International Law Commission states that 'the current state of international

82 Christian Tams, Enforcing Obligations Erga Omnes in International Law (Cambridge University Press, 2005), 197.

83 Ibid 197.

84 Ibid 197. Note that the International Court of Justice had the following to say on the topic:

the Court deems it necessary to recall that the mere fact that rights and obligations erga omnes or peremptory norms of general international law (jus cogens) are at issue in a dispute cannot in itself constitute an exception to the principle that its jurisdiction always depends on the consent of the parties.

Armed Activities on the Territory of the Congo (New Application: 2002) (Democratic Republic of the Congo v Rwanda) (Judgment) [2006] ICJ Rep 6, 52 [125].

85 See Supplementary Convention on the Abolition of Slavery art 10; Slavery Convention art 8 as amended by the provisions of the Annex to the 1953 Protocol Amending the Slavery Convention as reads:

The High Contracting Parties agree that disputes arising between them relating to the interpretation or application of this Convention shall, if they cannot be settled by direct negotiation, be referred for decision to the International Court of Justice. In case either or both of the States Parties to such a dispute should not be parties to the Statute of the International Court of Justice, the dispute shall be referred, at the choice of the Parties and in accordance with the constitutional procedure of each State either to the International Court of Justice or to a court of arbitration constituted in accordance with the Convention of October 18th, 1907, for the Pacific Settlement of International Disputes, or to some other court of arbitration.

86 Vienna Convention on the Law of Treaties, art 66.

87 Responsibility of States for internationally wrongful acts, GA Res 56/83, UN GAOR, 56th sess, 85th plen mtg, Agenda Item 162, UN Doc A/RES/56/83 (12 December 2001) art 54, reads:

This chapter does not prejudice the right of any State, entitled under article 48, paragraph 1, to invoke the responsibility of another State, to take lawful measures against that State to ensure cessation of the breach and reparation in the interest of the injured State or of the beneficiaries of the obligation breached. 
law on countermeasures taken in the general or collective interest is uncertain'. ${ }^{88}$ That said, having surveyed State practice, Professor Tams concludes 'that present-day international law recognizes a right of all States, irrespective of individual injury, to take countermeasures in response to large-scale or systematic breaches of obligations erga omnes' ${ }^{89}$ In other words: 'a general right to take countermeasures would be restricted to serious breaches of obligations erga omnes' ${ }^{90}$

In sum, where there are obligations erga omnes flowing from violations such as those in regard to the prohibition of slavery, those obligations owed to a third State are the same as those that would be owed to an injured State where an 'ordinary' wrongful act transpired. This holds, but for the proviso that there are additional obligations flowing erga omnes when, as we shall see, a serious breach transpires of peremptory norms of general international law.

In the case of the enslavement of thousands of Yazidi girls and women by ISIS, the question might be asked: if the legal interests to be protected are being violated by an actor which is not recognised as a State, does there exist State obligations erga omnes? The short answer appears to be no, as there is no responsible State to which might be directed actions under obligations erga omnes. That said, in the case of non-State entities such as ISIS, the longer answer might be to point to Article 10 of the Article of State Responsibility in regard to insurrectional movements wherein three options are possible: first, if ISIS was to become the new government of either Iraq or Syria, its conduct would 'be considered an act of that State under international law'; or second, if ISIS was to succeed in establishing a new State in part of the territory of either/or Iraq and Syria, then its conduct would be, "considered an act of the new State under international law' ${ }^{91}$ In both these instances, as a State - the actions in regard to the prohibition of slavery would become attributable to it as an act of State for the purposes of responsibility. The third and final possibility is if the ISIS insurrection were to fail, then Iraq and/or Syria would have obligations flowing from the prohibition of slavery to investigate and prosecute those responsible for the enslaving of Yazidi girls and women. Yet, this answer is rather unsatisfactory as it fails to engage with the essence of obligations erga omnes: that there are fundamental values of the international community which all States have an interest in protecting; and, as a result, such values require action by the international community so as to ensure their protection.

This consideration will become clear as our attention turns to consider those 'additional' obligations which flow erga omnes when there is a serious breach of peremptory norms of general international law. Recognising that the prohibition of slavery is indeed a peremptory norm of general international law, ${ }^{92}$ it will now be shown that the treatment of Yazidi women and children meets the threshold of a 'serious' breach of a jus cogens norm which would normally allow for the possibility of invoking these additional obligations erga omnes. Yet, it

88 'Report of the International Law Commission on the Work of Its Fifty-Third Session (23 April - 1 June and 2 July - 10 August 2001)’ [2001] II(2) Yearbook of the International Law Commission 1, 139.

89 Christian Tams, Enforcing Obligations Erga Omnes in International Law (Cambridge University Press, 2005), 250.

90 Ibid 248. Note that the Institute of International Law considers that where there is a serious breach of a norm of jus cogens, States are entitled, erga omnes, also to 'take non-forcible counter-measures under conditions analogous to those applying to a State specially affected by the breach'. See M. Giorgio Gaja, 'Obligations and Rights Erga Omnes in International Law' (2005) Institut de Droit International 1, art 5(c).

91 'Report of the International Law Commission on the Work of Its Fifty-Third Session (23 April - 1 June and 2 July - 10 August 2001)’ [2001] II(2) Yearbook of the International Law Commission 1, 50.

92 In its Commentary on the 2001 Articles on States Responsibility, the International Law Commission confirmed its earlier understanding — related to the Vienna Convention on the Law of Treaties — of the prohibition of slavery as a norms of jus cogens, stating that those 'peremptory norms that are clearly accepted and recognized include the prohibitions of aggression, genocide, slavery, racial discrimination, crimes against humanity and torture, and the right to self-determination'. See ibid 85. Emphasis added. 
needs to be recognised that the Articles on State Responsibility clearly attribute responsibility to States - and that in the considerations which follow, the invocation of primary responsibility by reference to Article 10, relating to either the States of Iraq and Syria, or possibly ISIS, can only be considered once the dust of the insurrection has settled. As a result, this sends considerations of the very regime of State Responsibility, and invoking obligations erga omnes, to an indeterminate horizon.

Returning to the question of the threshold of a 'serious' breach of a peremptory norm of general international law, the Commentary to the Articles on State Responsibility does well to provide guidance to the barebones of Article 40(2). The Commentary considers this threshold in the following manner: 'an obligation is serious if it involves a gross or systematic failure by the responsible State to fulfil the obligation' ${ }^{93}$ The International Law Commission notes in this Commentary that: 'the word 'serious' signifies that a certain order of magnitude of violation is necessary', before going on to consider the notions of 'gross' and 'systematic':

To be regarded as systematic, a violation would have to be carried out in an organized and deliberate way. In contrast, the term 'gross' refers to the intensity of the violation or its effects; it denotes violations of a flagrant nature, amounting to a direct and outright assault on the values protected by the rule. The terms are not of course mutually exclusive; serious breaches will usually be both systematic and gross. Factors which may establish the seriousness of a violation would include the intent to violate the norm; the scope and number of individual violations; and the gravity of their consequences for the victims. 94

Measured against these criteria, it is difficult to see how the mass enslavement of Yazidi girls and women does not constitute a serious breach of a peremptory norm of general international law. As to the order of magnitude of the violation of the prohibition of slavery, in January 2018, the United Nations Secretary-General reported that nearly four years after the overrunning of Sinjar, '1,507 Yazidi women and girls were reportedly still in [ISIS] captivity'. ${ }^{95}$ The 'scope and number of individual violations' of the prohibition of slavery which transpired against the Yazidi speaks to its serious nature.

Turning to consider the 'systematic' nature of the breach, the fact that it was organised and carried out in a deliberate manner is evident by the logistics put in place of transportation, holding, and sale of the Yazidi girls and women. In effect, this was not simply the enslavement of Yazidi girls and women, rather in law it was the establishment of a slave trade. It will be recalled that under the 1966 Covenant on Civil and Political Rights, not only is there a prohibition of slavery, but rather that 'slavery and the slave-trade in all their forms shall be prohibited' ${ }^{96}$ The definition of the slave trade was first set out in the 1926 Slavery Convention in regard to abolition; 97 but was also included in the 1956 Supplementary Convention on the Abolition of Slavery as being prohibited. ${ }^{98}$ In 2016, the Inter-American Court of Human Rights cited with approval the original 1926 definitions of the slave trade as being applicable to the American Convention, which like other instruments of international human rights law, mentions the slave trade by name but does not define it. This internationally recognised definition of the slave trade reads:

93 Responsibility of States for internationally wrongful acts, GA Res 56/83, UN GAOR, 56th sess, 85th plen mtg, Agenda Item 162, UN Doc A/RES/56/83 (12 December 2001) art 40(2).

94 See 'Report of the International Law Commission on the Work of Its Fifty-Third Session (23 April - 1 June and 2 July - 10 August 2001)’ [2001] II(2) Yearbook of the International Law Commission 1, 113.

95 Implementation of resolution 2367 (2017) - Report of the Secretary-General, UN Doc S/2018/677 (9 July 2018) [50].

96 International Covenant on Civil and Political Rights, opened for signature 19 December 1966, UNTS 999 (entered into force 23 March 1976) art 8.

97 Slavery Convention, art 1.

98 Supplementary Convention on the Abolition of Slavery, art 1. 
The slave trade includes all acts involved in the capture, acquisition or disposal of a person with intent to reduce him to slavery; all acts involved in the acquisition of a slave with a view to selling or exchanging him; all acts of disposal by sale or exchange of a slave acquired with a view to being sold or exchanged, and, in general, every act of trade or transport in slaves. 99

This definition should be read by reference to the prohibition of slavery, as setting out a number of acts committed in violation of that prohibition. ${ }^{100}$

Where the 'gross' nature of the enslavement of Yazidi girls and women is concerned, ISIS itself has acknowledged that this was a 'large-scale enslavement' of Yazidi girls and women. The violations of the prohibition of slavery were clearly flagrant and premeditated, and as such, it would be difficult to come to any other conclusion than that the actions of ISIS amounted to a 'direct and outright assault on the values protected by the rule' which prohibits slavery. Where the element of 'seriousness' is concerned, intent was made clear and forthright by ISIS; the scope and number of individual violations numbering in the thousands also speaks to the seriousness of the violation of a peremptory norm of general international law prohibiting slavery. Finally, in regard to the gravity of consequences for the victims, it will be recalled that by the end of 2018 more than 1,500 girls and women remained enslaved. As for those Yazidi girls and women who are no longer enslaved, the effects have left the survivors 'shattered', 'with many experiencing suicidal thoughts, and intense feelings of rage interspersed with periods of deep depression and listlessness'. 101

Accepting that the actions of ISIS in regard to Yazidi girls and women constitute what would normally be a 'serious' breach of the peremptory norm prohibiting slavery, but that this situation is not currently attributable within the regime of States Responsibility, two issues should be considered. The first is what obligations would flow from a serious breach of the peremptory norm prohibiting slavery where attribution can be established? The second, whether, in the face of a serious breach of peremptory norms of general international law, the underlying logic of obligations erga omnes necessitates State action, even if such breaches transpire at the hands of a non-State entity such as ISIS?

Turning first to consider obligations erga omnes, where attribution for serious breaches of obligations arising under peremptory norms of general international law could be established. Article 41 of the Articles on State Responsibility mandates what is in essence three specific obligations incumbent on all States erga omnes: not to recognise 'as lawful a situation created by a serious breach'; not to 'render aid or assistance in maintaining that situation'; and to 'cooperate to bring to an end through lawful means' such a breach. ${ }^{102}$

In its 2004 Advisory Opinion on Wall in the Occupied Palestinian Territory, the International Court of Justice gave voice to the obligations erga omnes as they related to selfdetermination, noting that 'all States are under an obligation not to recognize the illegal situation resulting from the construction of the wall in the Occupied Palestinian Territory', and further that States are 'also under an obligation not to render aid or assistance in maintaining the situation created by such construction'. ${ }^{103}$ While Stefan Talmon has written that there is

99 Slavery Convention, art 1.

100 Before the mention by the Inter-American Court in 2016, one would have to hark back to the 1905 Muscat Dhows case, for any international jurisprudence related to the slave trade. See Muscat Dhows Case (France v Great Britain) (Award) (Permanent Court of Arbitration, 8 August 1905).

101 Human Rights Council, "They came to destroy": ISIS Crimes Against the Yazidis, 32nd sess, Agenda Item 4, UN Doc A/HRC/32/CRP.2 (15 June 2016) 33.

102 'Report of the International Law Commission on the Work of Its Fifty-Third Session (23 April - 1 June and 2 July - 10 August 2001)’ [2001] II(2) Yearbook of the International Law Commission 1, 29.

${ }^{103}$ Legal Consequences of the Construction of a Wall in the Occupied Palestinian Territory (Advisory Opinion) [2004] ICJ Rep 136, [159]. 
some practice in regard the prohibition of racial discrimination and the right to selfdetermination, there

is virtually no such practice to support a duty of non-recognition with regard to situations created by serious breaches of other jus cogens norms such as the prohibitions of slavery and the slave trade ... In view of the lack of State practice, it has rightly been questioned whether customary international law knows of a general duty of non-recognition of all situations created by a serious breach of jus cogens. 104

Where the prohibition of slavery and the slave trade are concerned, Professor Talmon's consideration of the lack of State practice around non-recognition may be best understood in light of the perception held during most of the $20^{\text {th }}$ century, that such obligations were moot, as they were thought to only attach to de jure slavery. That said, it does raise the question more generally about obligations erga omnes, as it relates to the prohibition of slavery. While the prohibition of slavery itself is recognised by general international law as creating obligations erga omnes, the parameters of those very obligations are also a product of general international law. Where the Commentary of the Articles on State Responsibility is concerned, the provisions related to non-recognition and not rendering aid and assistance appears to tacitly be accepted as reflecting general international law. This is so, as the obligation to cooperate, by comparison, is seen in another light by the International Law Commission.

Where the obligation to 'cooperate to bring to an end through lawful means any serious breach' of an obligation arising under peremptory norms of general international law, is concerned, the Commentary to Article 41(1) of the Articles on State Responsibility, notes that 'the provisions do not prescribe what form the cooperation should take 'due to the diversity of what such cooperation might entail; nor as regards the measures which might be taken in regard to the duty to cooperate. That said, the Commentary is rather emphatic in stating 'what is called for in the face of serious breaches is a joint and coordinated effort by all States to counteract the effects of these breaches'. ${ }^{105}$ Yet, in its considerations, the Commission appears to acknowledge that in putting forward the provisions of Article 41(1), it is not necessarily codifying an established positive duty to cooperate, but rather seeking to strengthen the protection which should be afforded norms which, if breached in a serious manner, are of interest to the international community as a whole. The Commentary makes this plain in stating that 'it may be open to question whether general international law at present prescribes a positive duty of cooperation, and paragraph 1 in that respect may reflect the progressive development of international law'. ${ }^{106}$

For its part, three years after the finalisation of the Articles on State Responsibility, the International Court of Justice, in the 2004 Wall in the Occupied Palestinian Territory Advisory Opinion, did not fully endorse a positive duty to cooperate, rather it spoke in negative terms in the sense that it is for 'all States, while respecting the United Nations Charter and international law, to see to it that any impediment' to the exercise of the right to self-determination 'is brought to an end'. ${ }^{107}$ What may be drawn from this reading by the International Court of Justice is that such a situation must be 'brought to an end', and that this must transpire by lawful

\footnotetext{
104 See Stefan Talmon, 'The Duty Not to 'Recognize as Lawful' a Situation Created by the Illegal Use of Force or Other Serious Breaches of a Jus Cogens Obligation: an Obligation without Real Substance?' in Christian Tomuschat and Jean-Marc Thouvenin (eds), The Fundamental Rules of the International Legal Order: Jus Cogens and Obligations Erga Omnes (Brill | Nijhoff, 2005) 99, 103.

105 'Report of the International Law Commission on the Work of Its Fifty-Third Session (23 April - 1 June and 2 July - 10 August 2001)' [2001] II(2) Yearbook of the International Law Commission 1, 114.

106 Ibid.

${ }^{107}$ Legal Consequences of the Construction of a Wall in the Occupied Palestinian Territory (Advisory Opinion) [2004] ICJ Rep 136, [159].
} 
means. However, the Court, while recognising that States have obligations erga omnes, does not include a positive duty to cooperate, but rather overall obligations not to recognise, not to render aid and assistance, and not to get in the way of those who might wish to mend the breach. Having considered in general terms, the obligations which flow from a serious breach of a peremptory norm of general international law, where attribution is possible, attention now turns to consider whether, in the face such a serious breach of the prohibition of slavery by ISIS, the underlying logic of obligations erga omnes necessitates State action, including a duty to 'cooperate to bring to an end through lawful means' such a breach. ${ }^{108}$ Where a serious breaches of an obligation arising under peremptory norms of general international law is concerned, the International Law Commission has noted that the obligation arises 'from those substantive rules of conduct that prohibit what has come to be seen as intolerable because of the threat it presents to the survival of States and their peoples and the most basic human values'.109 Likewise, in its consideration of obligations erga omnes, the Institute of International Law, noted that 'under international law, certain obligations bind all subjects of international law for the purposes of maintaining the fundamental values of the international community'. ${ }^{110}$

As the values to be protected are those that, if breached, threaten the very existence of the State system, there is clearly an interest in all States ensuring that these are respected. Because of the values which underlie the obligations arising erga omnes to cooperate to bring a serious breach of a peremptory norm of international law to an end, such cooperation should not be seen as being exclusively applicable to situations in which a State is in violation. This is so, as States should no more tolerate a breach of the prohibition of slavery by an entity such as ISIS than they should were such a breach to transpire at the hands of a State. As a result, the fundamental logic of 'a positive duty to cooperate in order to bring to an end through lawful means' serious breaches of obligations arising under a peremptory norm of general international law, appears to still hold: that failing to do so, threatens the State system. ${ }^{111}$

Although we are moving beyond the realm of State Responsibility in considering the duty to 'cooperate to bring to an end through lawful means any serious breach', the Commentary of the International Law Commission on the Articles on State Responsibility does recognise that such cooperation does transpire:

But in fact such cooperation, especially in the framework of international organizations, is carried out already in response to the gravest breaches of international law and it is often the only way of providing an effective remedy. [The provision on cooperation of Article 41] seeks to strengthen existing mechanisms of cooperation, on the basis that all States are called upon to make an appropriate response to the serious breaches. ${ }^{112}$

In the context of a duty to cooperate, it would appear that the action of third States may not be driven by the essence of a lex lata duty to carry out such an obligation erga omnes; but rather the addressing of serious breaches of peremptory norms of general international law are best understood as interests in need of protection by the international community as a whole. The International Law Commission emphasises such communal cooperation 'could be organized in the framework of a competent international organization', and the reality of international relations is such that this remains the preferred option over individual States

\footnotetext{
108 'Report of the International Law Commission on the Work of Its Fifty-Third Session (23 April - 1 June and 2 July - 10 August 2001)’ [2001] II(2) Yearbook of the International Law Commission 1, 29.

109 'Report of the International Law Commission on the Work of Its Fifty-Third Session (23 April - 1 June and 2 July - 10 August 2001)’ [2001] II(2) Yearbook of the International Law Commission 1, 112.

${ }^{110}$ M. Giorgio Gaja, 'Obligations and Rights Erga Omnes in International Law' (2005) Institut de Droit International 1, preamble.

111 'Report of the International Law Commission on the Work of Its Fifty-Third Session (23 April - 1 June and 2 July - 10 August 2001)' [2001] II(2) Yearbook of the International Law Commission 1, 114.

112 Ibid 114.
} 
invoking obligations erga omnes in situations of serious breaches of peremptory norms of general international law. ${ }^{113}$ In other words, such a breach is more likely to be considered as a threat to international peace and security and dealt with by the United Nations Security Council, than a serious breach of a peremptory norm of general international law for the purposes of invoking obligations erga omnes by a third State under the regime of State Responsibility.

This communal cooperation has, in fact, played out in the form of the United Nations Security Council taking the lead in addressing the serious breaches which have transpired at the hands of ISIS. In this regard, the fact that the regime of State Responsibility cannot be invoked while ISIS continues as an insurrectional movement does not undermine the logic of the communitarian protection envisioned and flowing from obligations erga omnes: that serious breaches of peremptory norms of general international law are interests worthy of protection by the international community as a whole.

To that end, the United Nations Security Council has called on States to cooperate in addressing the actions of ISIS beyond the realm of State Responsibility. The Security Council, by virtue of its Resolution 2379 of September 2017, moved to establish an Investigative Team 'to support domestic efforts in Iraq' to hold ISIS 'accountable by collecting, preserving, and storing evidence in Iraq of acts that may amount to war crimes, crimes against humanity and genocide', including in regard to the prohibition of slavery. In so doing, the Security Council has called 'on all other States to cooperate with the Team including through mutual arrangements on legal assistance, where necessary and appropriate, and in particular to provide it with any relevant information as appropriate they may possess pertaining to its mandate under this resolution'. 114

Yet, a consideration of the jurisdictional reach of the Investigative Team brings us back to the question posed at the start of this Section, as to the value of obligations erga omnes in regard to the prohibition of slavery transpiring in isolation. In the case of ISIS, the United Nations Security Council is not focused exclusively on slavery, but rather on holding ISIS members to account for the commission of acts 'which may amount to war crimes, crimes against humanity or genocide', including those:

involving murder, kidnapping, hostage-taking, suicide bombings, enslavement, sale into or otherwise forced marriage, trafficking in persons, rape, sexual slavery and other forms of sexual violence, recruitment and use of children, attacks on critical infrastructure, as well as its destruction of cultural heritage, including archaeological sites, and trafficking of cultural property. ${ }^{115}$

The enslavement of Yazidi girls and women is but one manifestation of the multifaceted breakdown of the international and domestic orders in Iraq and Syria which provided the opportunity for ISIS to gain a foothold in the region and carry out various acts in violation of the fundamental precepts of international law. ${ }^{116}$ ISIS, in establishing its de facto Caliphate within this power vacuum, rejected the State system as being a Western imposition and construct. The violations by ISIS of those fundamental precepts of the contemporary

113 Ibid 114. Note that the Commission 'also envisages the possibility of non-institutionalized cooperation', within the purview of Article 41 of the Articles on State Responsibility.

114 SC Res 2379, UN SCOR, 8052nd mtg, UN Doc S/RES/2379 (21 September 2017) para 2, Preamble paras 4, 10 .

115 Ibid Preambular paras 5, 4.

116 SC Res 2331, 7847th mtg, UN Doc S/RES/2331 (20 December 2016) para 12.

Note that the breakdown of the domestic order is also at play in Libya and parts of Nigeria, where violations of the prohibition of slavery have been noted by the United Nations. See Security Council Presidential Statement Condemns Slave Trade of Migrants in Libya, Calls upon State Authorities to Comply with International Human Rights Law, 8122nd mtg, UN Doc SC/13105 (7 December 2017); Security Council Al-Qaida Sanctions Committee Adds Boko Haram to Its Sanctions List, UN Doc SC/11410 (22 May 2014). 
international order are documented by the Commission of Inquiry on the Syrian Arab Republic and, as of 2018, under investigation by a body established by the United Nations Security Council to assist Iraq in bringing those responsible to justice. With this in mind, it would be difficult to conceive of a situation where a State sought to reintroduce slavery or the slave trade as a singular serious breach of peremptory norms of general international law engaging the possibility of other States invoking responsibility flowing from obligations erga omnes related to the prohibition of slavery. This is so, as the apparent lesson from the actions of ISIS is that the reintroduction of the slave trade was part of a more fundamental tearing of the fabric of international law. ${ }^{117}$

\section{Conclusion}

For 90 years obligations regarding slavery appeared to fade to black. From 1926 onwards, States came to understand their obligations as being related to de jure slavery: a consensus taking hold that having abolished laws allowing for slavery, no further action was necessary. However, the 2016 determination by the Inter-American Court of Human Rights that slavery existed both de jure, but also de facto, has provided the opportunity to consider what obligations flow from the international norm which outlaws slavery, including those erga omnes.

Since 1926, a significant shift has transpired in the normative content of slavery: it has evolved from being one of 'abolition', to requiring its 'prohibition'. Having considered the normative content of the prohibition of slavery, this study turned to consider the value-added of the prohibition of slavery as having been recognised as benefiting from obligations erga omnes.

In the first instance, the study examined treaty-based obligations erga omnes partes to demonstrate the extent to which States have failed to adopt domestic criminal legislation meant to prohibit slavery. In so doing, the study also showed that where an instrument prohibiting slavery is at play: so too are obligations erga omnes partes. As such, any State party to an instrument prohibiting slavery, though not directly injured by a violation by another State Party, can invoke the responsibility of that State, as the obligation is owed to all States Parties, by virtue of the instrument having been established to protect the collective interest in prohibiting slavery.

Beyond such obligations erga omnes partes, this study has demonstrated the extent to which obligations erga omnes may be invoked in regard to serious breaches of obligations arising under a peremptory norm of general international law. Turning to consider such a serious breach in regard to the prohibition of slavery, this study examined the case of the first wholesale re-introduction of the slave trade since the nineteenth century, namely that of Yazidi girls and women at the hands of the Islamic State of Iraq and Al-Sham. As ISIS is a non-State entity, it was acknowledged that no attribution for the purposes of State Responsibility is currently possible. That said, it was made plain that the lack of attribution did not absolve States from

117 The Security Council considers ISIS a 'global threat to international peace and security', as a result of:

its terrorist acts, its violent extremist ideology, its continued gross, systematic and widespread attacks directed against civilians, its violations of international humanitarian law and abuses of human rights, particularly those committed against women and children, and including those motivated by religious or ethnic grounds, and its recruitment and training of foreign terrorist fighters whose threat affects all regions and Member States. 
the need to cooperate to bring serious breach of peremptory norm of general international law to an end.

Ultimately, this study has provided the opportunity to consider State obligations, both erga omnes and otherwise, as they pertain to the prohibition of slavery. In so doing, the study bears witness to something which should have the reader pause to consider: the reintroduction of the slave trade after its absence of more than a century. With this in mind, the fact that the obligations undertaken by States in regard to the prohibition of slavery have been shown to be no longer hortatory, speaks to the need to carry these out in good faith. To that end, this study has brought to the attention of the reader the fact that nearly half of all States have failed to carry out their most basic of obligations: to have in place domestic legislation which criminalise the prohibition of slavery. 